\title{
PATTERNS OF GLACIAL EROSION AND DEPOSITION IN PRYDZ BAY AND THE PAST BEHAVIOUR OF THE LAMBERT GLACIER
}

\author{
by P.E. O'Brien and P.T. Harris
}

(with eleven text-figures)

O'Brien, P.E. \& Harris, P.T., 1996 (xi): Patterns of glacial erosion and deposition in Prydz Bay and the past behaviour of the Lambert Glacier.In Banks, M.R. \& Brown, M.J. (Eds): CLIMATIC SUCCESSION AND GLACIAL HISTORY OF THE SOUTHERN HEMISPHERE OVER THE LAST FIVE MILLION YEARS. Pap. Proc. R. Soc. Tasm. 130(2): 79-85. 1SSN 0080-4703. Antarctic CRC, Australian Geological Survey Organisation, GPO Box 378 Canberra, ACT, Australia 2601 (PEO) and Antarctic CRC, Australian Geological Survey Organisation,University of Tasmania, GPO Box 252-80, Hobart, Tasmania, Australia 7001 (PTH).

Styles of glacial sedimentation and erosion in Prydz Bay respond to glacial and interglacial cycles and fall into three zones; an inner zone of net erosion, a middle zone of subglacially eroded and deformed transitional glacial marine deposits and an outer zone of subglacial till deposition and shelf progradation. The inner zone is the region of maximum basal shear stress and inner-shelf deep formation by enhanced erosion in areas where tributary glaciers converge with the extended Lambert Glacier. The middle zone is underlain by sediments deposited near the ice-grounding zone during retreat, both as blanker-like deposits and as grounding-line moraines. This material is then deformed into elongate subglacial bedforms (megaflutes or drumlins), a process that probably involves some erosion. Deforming subglacial bed conditions extend to the shelf edge within a valley crossing the shelf on the western side of Prydz Bay. The outer zone is a zone of net deposition of compact subglacial till and prograding continental slope deposits formed during full glacial conditions and glacial marine sediment formed during ice retreat. The inferred build up of ice on the Ingrid Christensen Coast may have been responsible for the development of the western ice stream that flowed in Prydz Channel. The geometry of seismic sequences in Prydz Channel suggests that this ice stream and its associated trough mouth fan developed after a major episode of shelf and slope erosion during the Pliocene.

Key Words: Prydz Bay, glacial history, Lambert Glacier, Amery Ice Shelf, Antarctica, seismic reflection, marine geology.

\section{INTRODUCTION}

The understanding of Northern Hemisphere ice sheets has depended greatly on the observation of the geomorphology, stratigraphy and sedimentology of sediments deposited around their margins (e.g. Dardis \& McCabe 1994). To develop similar levels of understanding of the Antarctic Ice Sheet, we must look to the continental shelf and slope for the same type of information as is provided by the depositional edges of the Laurentian and European Ice Sheets. The data necessary to provide this analysis for Antarctica is acquired by seismic reflection, coring and drilling techniques and has been concentrared in the Ross and Weddell Seas, the Antarctic Peninsula and Prydz Bay. Prydz Bay is a significant location for such work, because it is the downstream, depositional end of the Lambert Glacier. The Lambert Glacier's behaviour should reflect the overall state of the East Antarctic Ice Sheet better than any other glacier because it drains such a large proportion of East Antarctica (Allison 1979) and it has deposited moraines in its middle reaches, in the Prince Charles Mountains, so there is potential to develop a picture of the glacier's fluctuations along its length.

The broad characteristics of Antarctic shelf glaciation have been outlined by numerous studies using seismic data, sea-bed sampling and ODP drilling (e.g. Larter $\&$ Barker 1989, Hambrey et al. 1991, Anderson 1991, Cooper et al. 1991a). Ten Brink \& Schneider (1995) demonstrated that the large-scale sequence geometry of the Antarctic shelf can be modelled as the result of long-term inner shelf erosion and shelf-edge deposition by glaciers advancing to the shelf edge, and Cooper et al. (1991a) documented the existence of both aggradational and progradational glacial sequences around the Antarctic margin. These studies have predominantly used low frequencey seismic data to define the overall sequence geometry, but to investigate the characteristics of individual glacial systems it is necessary to collect higher frequency data (King et al. 1991, Alonso et al. 1992) and to consider the origin of sea-floor landforms (Barnes 1987, O’Brien 1994).

Prydz Bay has received more attention than other parts of the East Antarctic continental shelf and slope with multichannel seismic surveys (Stagg 1985, Mizukoshi et al. 1986, Kuvaas \& Leitchenkov 1992), marine sampling (O'Brien et al. 1995), five deep holes drilled by the Ocean Drilling Program (ODP Leg 119; Barron Larsen et al. 1991) and, most recently, an intermediate resolution seismic survey (O'Brien et al. 1995). Low-frequency, multichannel seismic data has provided images of the deep structure of the bay and the broad stratigraphic framework, but a clearer picture of the glacial geology of the bay is emerging from higher resolution seismic data and echo sounder records (O'Brien 1994). This study uses the $3.5 \mathrm{kHz}$ echo sounder and low-frequency, multichannel seismic data collected on the marine geoscience cruise by Australian National Antarctic Research Expeditions (ANARE) on the MV Nella Dan in 1982 (Stagg 1985), gravity cores collected by ANARE in 1993 (O'Brien et al. 1993) and intermediate resolution seismic data collected in 1995 to define the distribution of glacial erosion and deposition in Prydz Bay. The result of this work can be used to produce a map of the different bed types beneath the Lambert Glacier when it extended to the shelf edge, the relative contibution of ice from around the bay, and to infer the timing of some changes in its behaviour. 


\section{GEOMORPHIC SETTING}

Prydz Bay is occupied by a broad topographic basin, the Amery Depression, which deepens shoreward (fig. 1). Depressions of up to $1000 \mathrm{~m}$ are found in the southwestern corner of the bay (the Lambert and Nanok Deeps), and running parallel to the Ingrid Christensen Coast is an elongated trough up to $1000 \mathrm{~m}$ deep, the Svenner Channel (fig. 1). Another elongate deep, the Prydz Channel, extends to the continental shelf along the western edge of the Amery Depression (fig. 1). Prydz Channel resembles shelf-crossing valleys seen in the Ross Seas, with similar width to depth ratio (Alonso et al. 1992). The Svenner Channel, however, is not a simple channel but has several shallower saddles along its axis, offshore from areas of exposed bedrock in the Larsemann and Vestfold Hills (fig. 1). Offshore from the Amery Depression, the shelf shallows to less than $200 \mathrm{~m}$ deep along the shelf edge, forming the Four Ladies Bank on the eastern side of the Prydz Channel and Fram Bank on the western side (fig. 1). The topography of Prydz Bay is rugged along its southeastern flanks, between the edge of the Svenner Channel and the present coast. Large, U-shaped valleys extend northwest from the termini of the Sorsdal, Ranvick and Polar Record Glaciers. The area close to the Amery Ice Shelf front features broad valleys separated by narrow ridges trending parallel to ice flow (O'Brien 1994).

The continental slope adjacent to Prydz Bay consists of a large trough mouth fan offshore from the Prydz Channel and a steeper part offshore from Four Ladies Bank, that is cut by dendritic tributaries of the Philippi Canyon (Vanney $\&$ Johnson 1985). The Prydz Channel Fan extends $90 \mathrm{~km}$ seaward from the shelf break and is $166 \mathrm{~km}$ across, with surface slopes of $1.3^{\circ}$. It lacks submarine canyons.

\section{EROSION-DEPOSITION AS SEEN ON SEISMIC SECTIONS}

The broad patterns of erosion and deposition by the Lambert Glacier can be defined by examining long seismic sections that cross the bay from near the Amery Ice Shelf to the continental shelf edge (e.g. BMR 33-27 P1 \& P2, figs 2, 3). Three zones can be recognised (fig. 3):

1. The inner zone corresponds to the deepest inshore parts of the Amery Depression. Correlation to ODP Leg 119 holes indicates that the preglacial Mesozoic sediments of the Lambert Graben are truncated at the sea floor or at the base of the youngest sequence visible on the section. The most recent sediments in this zone form a thin, seaward-thickening blanket draping the surface. In addition, there is a groundingzone moraine in Mackenzie Bay on the western side of the Amery Depression and another offshore from the Publication Ice Shelf (G. Leitchenkov, pers. comm. 1994).

2. Within the middle zone, older, preglacial sequences are truncated and several glacial sequences overlie them (fig. 3). These lower glacigene units display parallel reflection geometry, which Cooper et al. (1991a) interpreted as deposited by vertical aggradation. Correlation to ODP Leg 119 holes indicates that these strata are of late Eocene to Oligocene age (Hambrey et al. 1991).

3. Within the outer zone, the shelf comprises foresets, formed by progradation of debris that was transported to the shelf edge in basal ice or at the glacier bed. Some parts of this zone have flat-lying topset beds overlying the foresets. These topsets are thicker beneath the Four Ladies Bank than in the

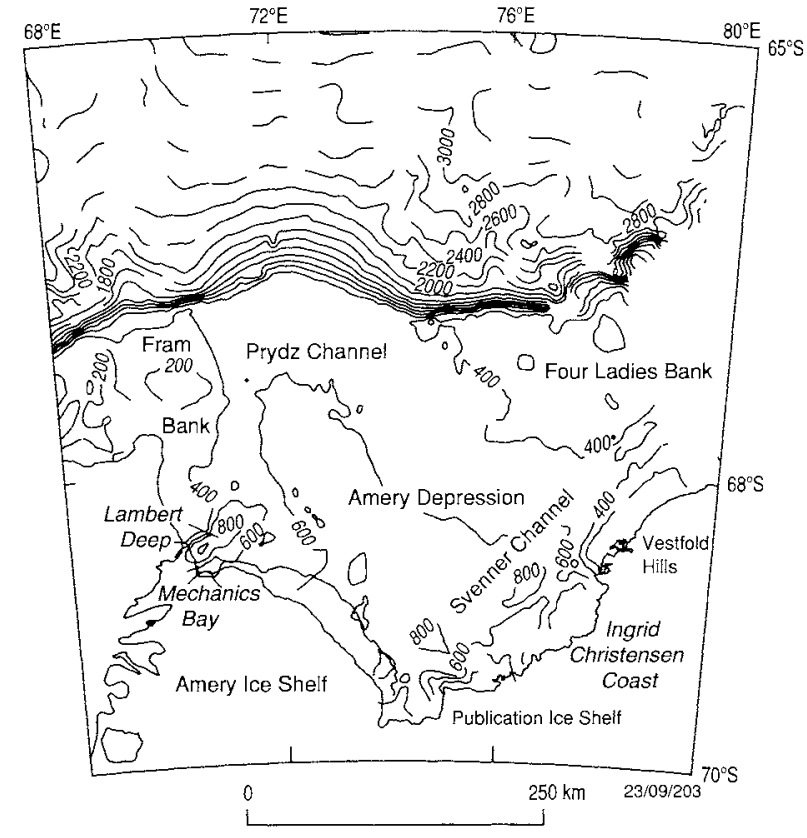

FIG. 1 - Bathymetry and major features of Prydz Bay.

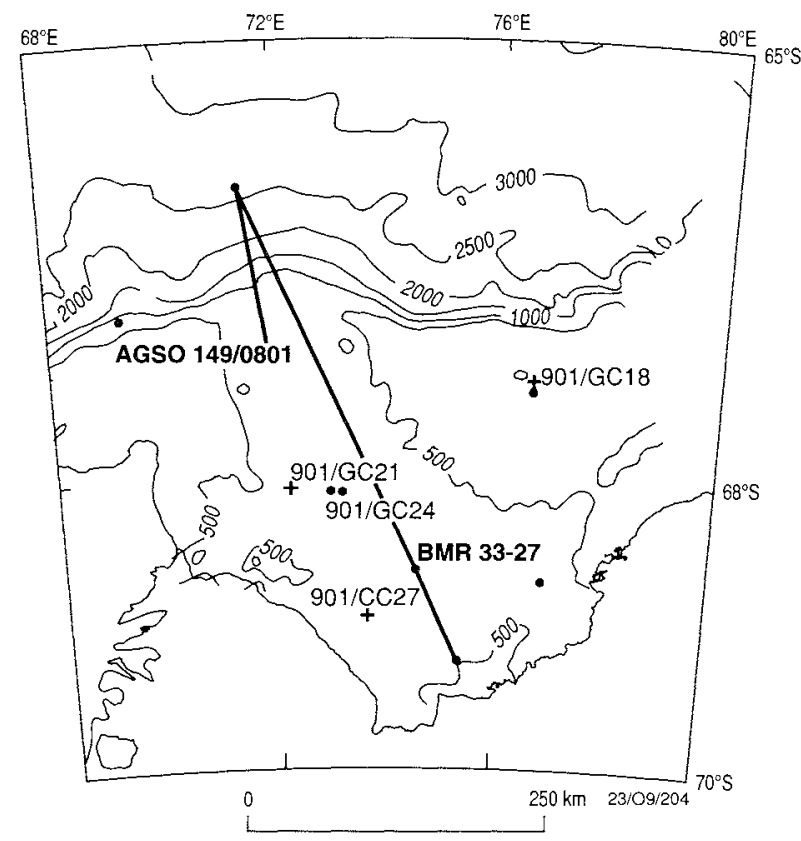

FIG. 2 - Locations of seismic lines and gravity cores referred to in this study. Line BMR 33-27 was collected by the MVNella Dan in 1982 using a $10 \mathrm{~L}$ air gun and $600 \mathrm{~m}$ streamer (Stagg 1985), Line AGSO 149/0801 by the RSV Aurora Australis in 1995 using a $3 \mathrm{~L}$ GI (generator-injector) airgun and $25 \mathrm{~m}$ streamer (O'Brien et al. 1995). Gravity cores (901/GC18, $901 / G C 21,901 / G C 24,901 / G C 27)$ collected by the RSV Aurora Australis during 1993 (O'Brien et al. 1993).

Prydz Channel. Their relationship to the foresets is variable. An intermediate resolution line from Prydz Channel (fig. 4) shows a progression from clinoforms with horizontal topsets passing continuously into the foresets, with the palaeoshelf edge rising as well as moving seaward, into clinoforms with topsets that are very thin or absent. This style of clinoform 


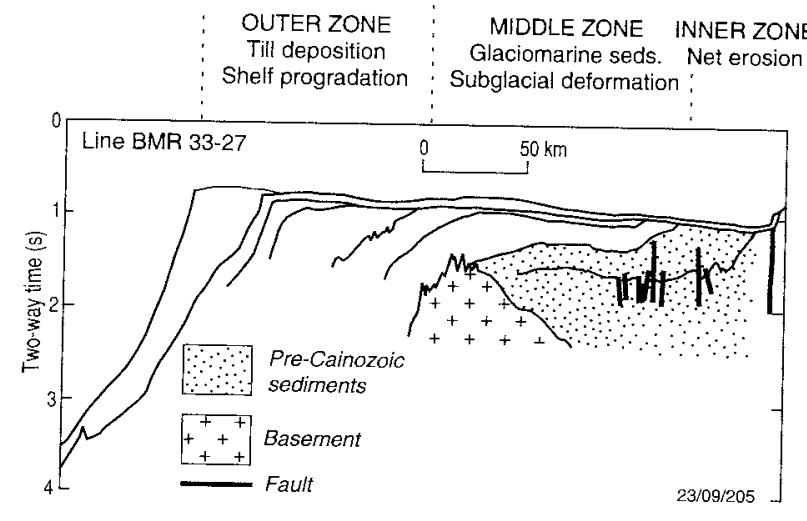

FIG. 3 - Zonation of Prydz Bay as seen on multichannel seismic line BMR33-27. The inner part of the shelf is a zone of net erosion with inner shelf troughs and pre-glacial sediments of the Lambert Graben truncated beneath thin glacigene sediments. The middle zone features transitional glacimarine and subglacially deformed sediments and the outer zone, dipping foresets formed by slope progradation and subglacial till deposited on banks.

is succeeded by a prominent, undulating erosion surface, that can be traced back to ODP site 739. Diatoms in ODP site 739 suggest a probable Pliocene $(<4 \mathrm{Ma})$ age for the surface (Baldauf \& Barron 1991). Seaward of this surface, clinoforms consist of topsets with a gentle seaward dip and numerous downlap surfaces. These clinoforms are succeeded by another major downlap surface and then by clinoforms lacking high-amplitude reflectors with, apparently, no topset beds. The uppermost sequence in this zone is a thin blanket of sediment that is affected by iceberg plough marks.

\section{EROSION-DEPOSITION AS SEEN IN MAP VIEW}

Examination of the grid of seismic sections enables a map of the different subglacial depositional zones to be produced. These zones can be further subdivided when geomorphic features on $3.5 \mathrm{kHz}$ echo sounder records and core facies are considered. Figure 5 is a map based on the echo sounder character map of O'Brien (1994) but uses core data to infer depositional characteristics in the area of intense iceberg ploughing. The current depositional state of the areas is not included in this interpretation.

Zone 1: This zone is one of predominant erosion. Seismic lines show acoustic basement or sediments which correlate with Mesozoic strata in ODP holes very close to the sea floor. Post-Cainozoic sediment, when present, is in thin veneers of sandy muds and diamictons overlain by post-glacial diatomaceous ooze or grounding-zone moraines. Inner shelf deeps are present in the southwestern corner of the bay.

Zone 2: On the floor of much of the Amery Depression and Svenner Channel, O'Brien (1994) identified sediment ridges on $3.5 \mathrm{kHz}$ echo sounder records (fig. 6). The appearance of these ridges on intersecting profiles indicated that they trend parallel to the probable former ice-flow direction. These features are of the same scale as drumlins or megaflutes (Hambrey 1995) formed by erosional bed deformation beneath the glacier (Hart 1995). The length of individual ridges normal to profiles cannot be determined, making it difficult to classify them as either drumlins or megaflutes. Sediment cores contain unconsolidated, massive silts, pebbly muds and muddy diamictons beneath an ubiquitous veneer of sandy diatomaceous ooze (fig. 7A). The Prydz Channel was also probably a zone of bed deformation (Hambrey et al. 1991). Topset beds are thinner in the channel than the adjacent banks, suggesting bypass of subglacial sediment.

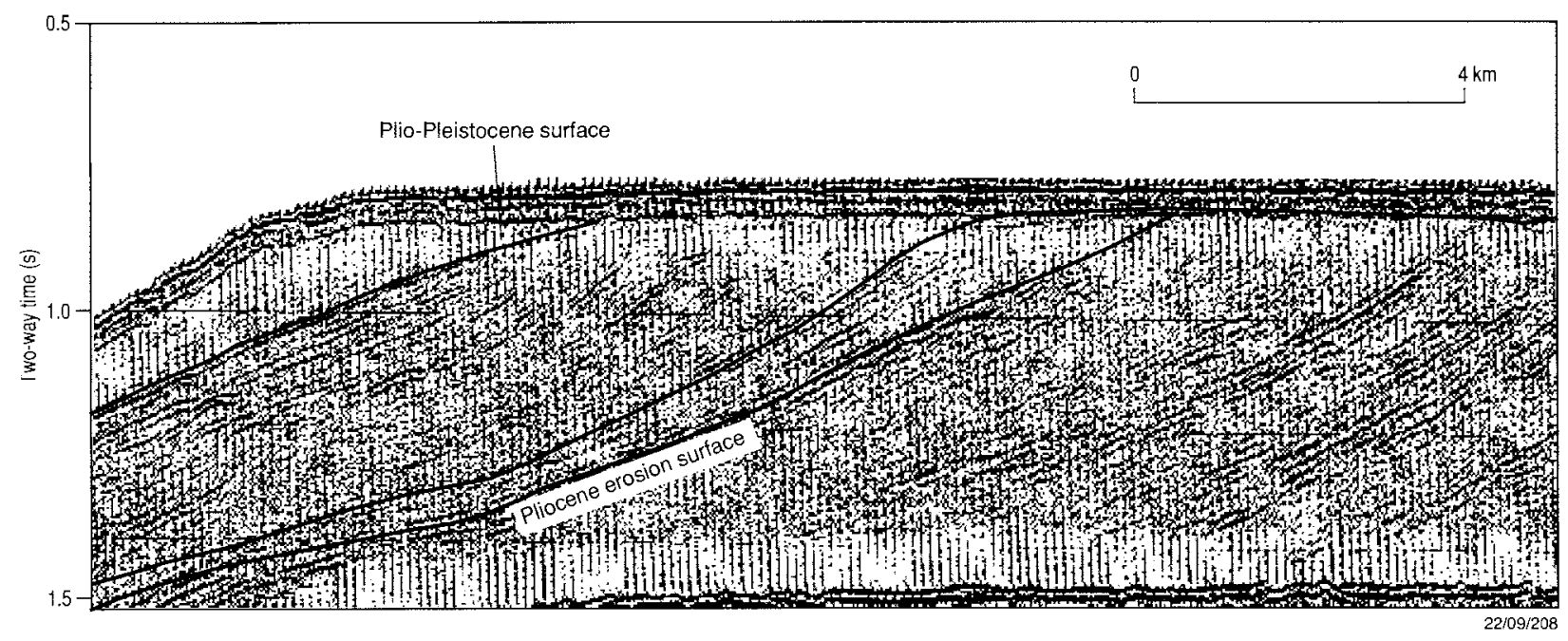

FIG. 4 - Part of AGSO Line 14910801 showing the seaward change from clinoforms lacking topsets to those with seawarddipping topsets and finally clinoforms lacking topsets in the most recent sequence. The major Pliocene surface formed by slope erosion just before the development of the fast-flowing ice stream that built the Prydz Channel trough mouth fan. 


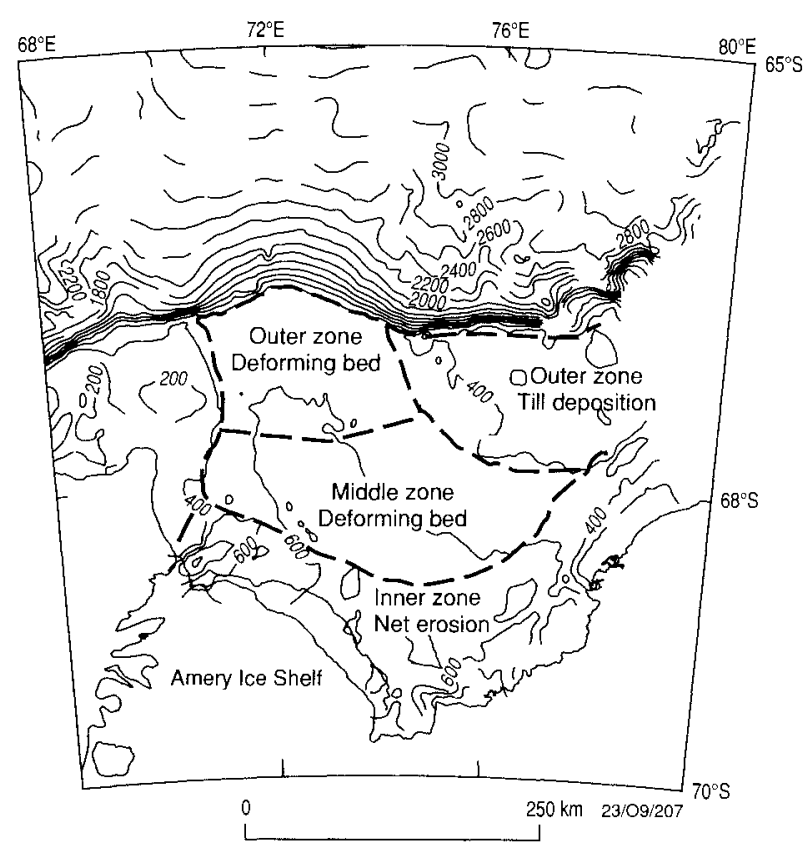

FIG. 5- Map of inferred zones beneath the Lambert Glacier during episodes of maximum extent in Prydz Bay.

Gravity cores from the channel do not encounter compact diamicton, rather they recover pebbly muds with brecciated textures (fig. 7B). These sediments could form as bedded glaciomarine muds during ice retreat which are then brecciated by subglacial deformation.

Zone 3: The Four Ladies Bank is mostly covered by iceberg plough marks, but O'Brien (1994) identified an area protected from ploughing. Cores from this area encountered thin postglacial sand overlying highly compact diamicton. This diamicton is probably subglacial till and constitutes the thick topset beds seen on seismic sections and encountered in ODP holes on the Bank.

\section{INTERPRETATION}

Considering a inshore-offshore transect, the arrangement of subglacial zones can be explained in terms of the distribution of basal shear and normal stress beneath the Lambert Glacier during its occupation of Prydz Bay. Subglacial erosion and deposition beneath sliding ice is a function of basal ice velocity and normal stress (Hallet 1981, Budd et al. 1979, Boulton 1990). Hart et al. (1990) described an idealised longitudinal distribution of basal shear stress beneath an ice sheet, and its relationship to bed deformation (fig. 8). Shear stress rises gradually from the ice divide, reaching a maximum beneath the position of the ice-sheet equilibrium line, then it falls rapidly towards the ice edge. The locus of maximum subglacial erosion will approximate the zone of maximum basal shear stress, with subglacial deposition coming in to play as shear stress falls towards the edge of the ice (fig. 8). Budd et al. (1979) showed that abrasion by ice depended on vertical stress as much as ice velocity, thus explaining the common observation of maximum depths of erosion beneath the thickest parts of glaciers. Thus, while fully extended, the Lambert Glacier was eroding the inner part of Prydz Bay and depositing compact subglacial till on the outer parr, producing the characteristic reverse bathymetric gradient on the shelf (ten Brink \& Schneider 1995).

This simple cross-section is complicated by the advance and retreat of the ice sheet with glacial cycles and by the deposition of glaciomarine sediment at or seaward of the grounding line. Numerous authors have identified massive muds and pebbly muds on the inner Antarctic Shelf as having been deposited by basal melting of debris at or near this line (e.g. Anderson et al. 1991). These are the transitional glacial marine sediments of Anderson et al. (1980). Such sedimenrs blanket much of inner Prydz Bay, including the zone of megaflutes identified by O'Brien (1994). Megaflutes and drumlins are thought to form in zones of subglacial deformation (Menzies 1989) and represent zones of net erosion (Hart 1995). Therefore, this

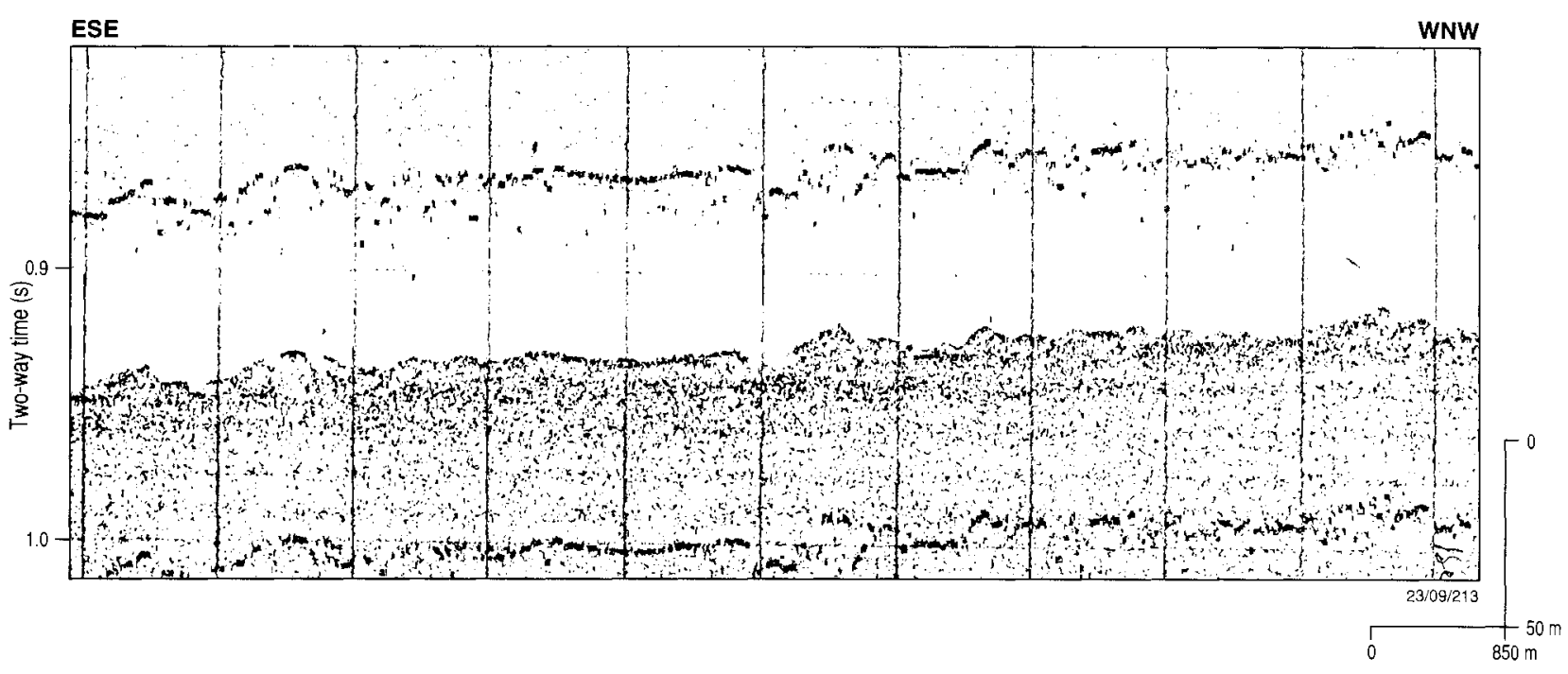

FIG. 6-Echo sounder (3.5. kHz) profile of drumlins or megaflutes on the floor of the Amery Depression. The orientation of these sea-floor ridges can be deduced from intersecting profiles. They are oriented normal to this WNW-oriented echo-sounder profile. The profiles do not allow the length of individual ridges to be deduced so their classification as megaflutes or drumlins is uncertain. They are interpreted as products of moulding of the glacier bed by grounded ice moving towards the NNE. 


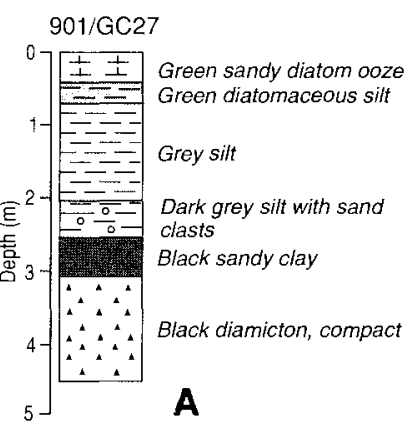

$901 / \mathrm{GC} 21$

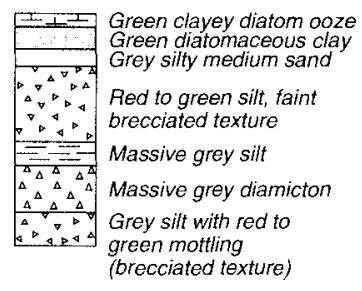

B $23 / 09 / 209$

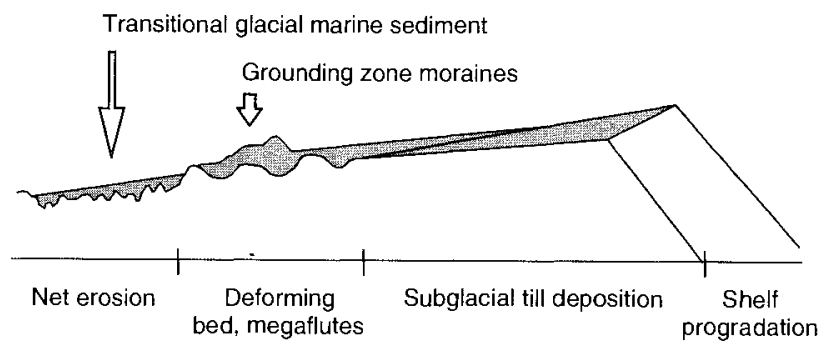

23/09/211

FIG. 7 - Lithological logs of gravity cores from Prydz Bay. (A) The sequence in the Amery Depression comprises massive, compact diamicton, possibly deposited subglacially, overlain by sandy clays and silts deposited beneath the ice shelf by basal melting, overlain by diatomaceous silts and ooze deposited in open water. (B) A core from Prydz Channel contains interbedded diamictons and silts that feature a brecciated texture which suggests subglacial bed deformation beneath the western ice stream. Diatomaceous sands and silts deposited in open water are the uppermost sediments.

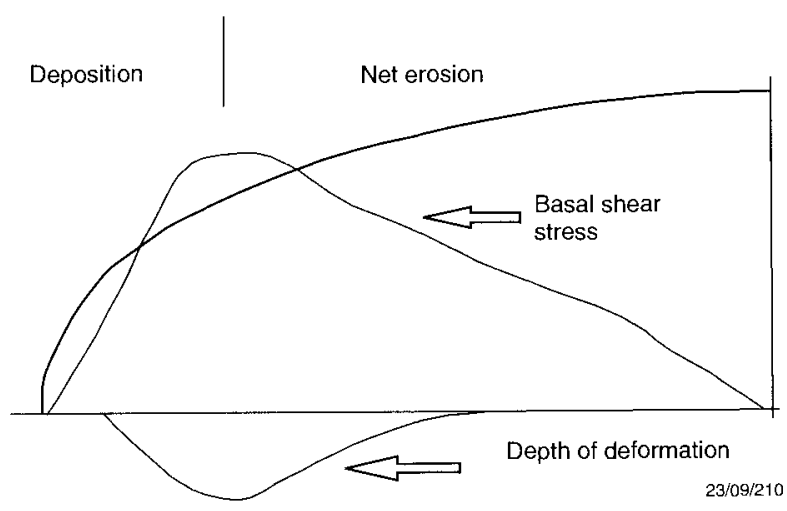

FIG. 8 - Idealised distribution of basal shear stress and bed deformation beneath an ice sheet (after Hart et al. 1990). During periods of maximum ice extent, the inner and middle zones of Prydz Bay corresponded to the zone of rising and maximum basal shear stress, resulting in overdeepening of the shelf. Falling basal shear stress results in till deposition on the Four Ladies Bank.

zone probably represents a region that receives glaciomarine sediments during the retreat of the grounding line. These sediments are then moulded into subglacial bedforms during re-advance. The presence of megaflutes on top of groundingline moraines suggests minor re-advances during moraine formation. Cores from the Amery Depression contain diamicton that is compact but not as consolidated as the subglacial tills recovered from Four Ladies Bank (fig. 7A). Amery Depression diamictons lack evidence of water sorting and marine microfossils, suggesting they are either tills or transitional glacial marine facies deposited by basal melting very close to the ice-shelf grounding zone (Anderson et al. 1991). Their relatively low compaction compared to tills on the Four Ladies Bank suggests that they are more likely to be transitional glacial marine sediments, although additional fabric work will be needed to confirm this (e.g. Eyles et al. 1987). The depositional setting would also favour the absence of tills from the most recent glacial sediments of the Amery Depression, because the grounding

FIG. 9 - Facies produced by one advance and retreat cycle of the Lambert Glacier in Prydz Bay. The ice cuts an erosion surface in the inner zone. The deforming bed zone is also eroded with previously deposited sediments deformed into megaflutes and drumlins. The amount of erosion decreases seaward until subglacial till is deposited on the outer bank. Debris that is not deposited beneath the ice melts out at the grounding zone at the shelf break, depositing on the the continental slope. As the ice retreats, it deposits transitional glacial marine muds and diamictons as a blanket and in grounding-line moraines. Megaflutes may still form close to the grounding zone. During interglacials, sandy, muddy ooze is deposited on the inner shelf and diatomaceous sands form a thin veneer on the outer shelf. The outer shelf is subject to iceberg ploughing.

zone would have retreated very rapidly down the reverse slope of the shelf as sea level began to rise. This would result in a very rapid fall in shear stress at the sediment-ice interface, producing a virtually instantaneous transition from erosional bed deformation to transitional glacial marine sedimentation.

The advance and retreat of the Lambert Glacier produces the model facies relationship shown in figure 9. Inner Prydz Bay is a zone of net erosion which passes out into iceretreat glaciomarine sediments and moraines that were eroded and deformed during periods of extended ice. The outer bank received subglacial till, followed by glaciomarine facies upon retreat of the grounding line.

When considering the regional picture of sedimentation in Prydz Bay, the cross-sectional view is complicated by the areal variations in ice behaviour. The main features to be considered are the position of inner shelf deeps and Prydz Channel. The deepest parts of Prydz Bay are the Lambert and Nanok Deeps in the southwestern corner of the bay and closed depressions in the floor of the Svenner Channel. The Lambert and Nanok Deeps clearly form at the confluence of the Amery/Lambert Glacier and ice flowing down Mechanics Bay (fig. 1). During glacial episodes, this confluence was a zone of thick ice and high normal stress and, hence, of increased erosion (Budd et al. 1979). The Svenner Channel exhibits shallower saddles offshore from the Larsemann Hills and Vestfold Hills and parallels the Ingrid Christensen Coast, unlike Prydz Channel, suggesting that it too was produced by erosion at the confluence of the Lambert Glacier and greatly expanded glaciers flowing from the southeast (fig. 10). Higher input from the southeastern side of Prydz Bay is consistent with the observations of modern precipitation (Allison 1979). High input from the southeastern side of the bay compared to the western side may have produced a northwesterly surface gradient, causing flow in that direction and the formation of Prydz Channel. 


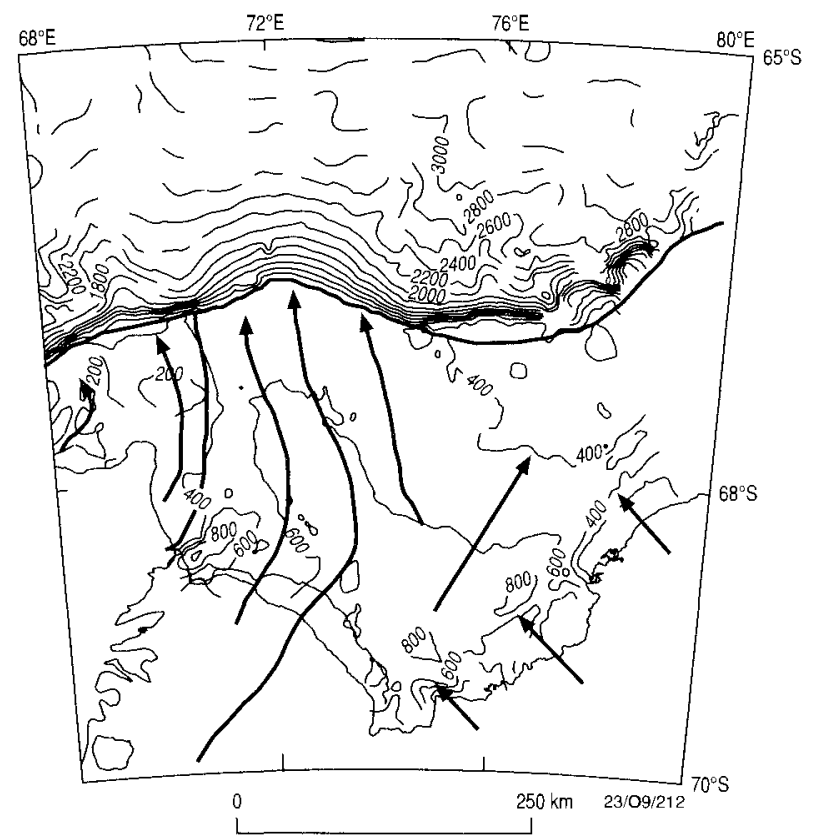

FIG. 10-Interpreted ice-flow paths for periods of maximum ice extent in Prydz Bay. The coincidence of the deepest parts of the bay with the confluences of the Lambert Glacier and smaller ice streams suggests significant input from the Ingrid Christensen Coast and Mac. Robertson Land glaciers.

Prydz Channel is typical of the cross-shelf troughs that were sites of a fast-flowing ice streams during glacial maxima (Vorren et al. 1989, Boulton 1990, Hambrey et al. 1991). The ice stream probably flowed over deforming beds (Alley et al. 1989). The high input of ice from the southeast may explain the location of the ice stream on the western side of Prydz Bay. Tectonic control cannot be invoked because the ice stream cuts across a east-northeast basement ridge (fig. 3). A hypotheses for the timing of the ice stream's formation can be developed by examining the seismic stratigraphy of the shelf on Line AGSO 149/0801. The inshore clinoforms with topsets have geometries similar to those of rhe Four Ladies Bank, where there was no such ice stream (Cooper et al. 1991b). The shelf prograded and aggraded during deposition. We interpret the clinoforms lacking topsets as similar aggradation/progradation clinoforms from which the topsets have been eroded (fig. 11). In this model, the glacial sedimentation was uniform across Prydz Bay, but then the ice stream formed and cut Prydz Channel, removing the topsets. This topset erosion surface passes into the prominent Pliocene downlap surface on the slope seen on figure 4 . Thus, the ice stream formed in the Pliocene less than $4 \mathrm{Ma}$ ago. The point at which this surface would reach the sea floor falls on a line joining the shelf edges on either side of the Prydz Channel Fan, suggesting that the surface is indeed the base of the fan.

The timing of Pleistocene advance and retreat cycles of the Lambert Glacier across Prydz Bay is still unclear. Domack et al. (1991) reported a corrected ${ }^{14} \mathrm{C}$ AMS date of $10600 \mathrm{yr}$ BP for the start of diatom ooze sedimentation at the site of ODP 741, using a reservoir correction of 1750 years. Gravity core 901/GC24 collected from the Amery Depression gives an uncorrected date of $12680 \pm$ 110 yr BP for the same facies change. This corrects to $11930 \mathrm{yr}$ BP, using the reservoir correction of Domack et al. (1991). This change from glaciomarine clays to diatom

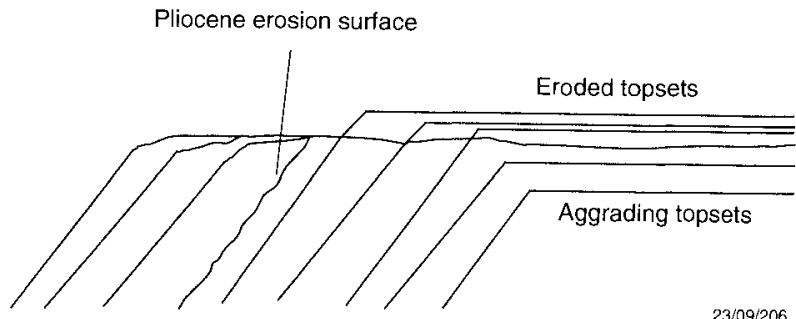

$23 / 09 / 206$

FIG. $I 1$ - Model for evolution of clinoforms in Prydz Channel. Clinoforms lacking topsets were deposited with topsets which were eroded by the western ice stream.

ooze represents the onset of open water sedimentation at the sites, but there are no dates for the transition from subglacial sediments to transitional glaciomarine facies. There is even less indication as to when the glacier grounding line advanced. The trough mouth fan is the most likely place to find datable sediments corresponding to ice advances.

\section{CONCLUSIONS}

Erosion and deposition by the Lambert Glacier in Prydz Bay fall into three zones:

(1) The inner zone forms in the region of maximum basal shear stress beneath the extended Lambert Glacier, and inner shelf deeps form by enhanced erosion in areas of thick ice, where tributary glaciers converge with the main glacier. The Svenner Channel can also be explained in terms of convergence of the Lambert Glacier with greatly enlarged glaciers flowing from the Ingrid Christensen Coast.

(2) The middle zone is underlain by transitional glacial marine sediments deposited during retreat, both as blanketlike deposits and as grounding-zone moraines. This material is deformed into elongate subglacial bedforms (megaflutes or drumlins), a process that probably involves some erosion. Deforming subglacial bed conditions extend to the shelf edge in the Prydz Channel.

(3) The outer zone is a zone of net deposition of compact subglacial till and prograding continental slope deposits, formed during full glacial conditions, and glacial marine sediment laid down during ice retreat.

The interpreted build-up of ice on the southeastern coast of Prydz Bay may have caused a northwesterly gradient on the ice surface and so produced flow in that direction, resulting in the development of the western ice stream that flowed in Prydz Channel. The geometry of seismic sequences in Prydz Channel suggests that this ice stream and its associated trough mouth fan developed after a major episode of shelf and slope erosion during the Pliocene.

\section{ACKNOWLEDGEMENTS}

We would like to thank Brian Dickinson, Simon Milnes, David Sewter, Heather Miller, Wojciech Wierzbicki and the Master and crew of the RSV Aurora Australis for their assistance in data acquisition. John Marshall, Doug Thost and an anonymous reviewer provided helpful comments on the manuscript and Jill Clarke prepared the figures. Published with the permission of the Director, Australian Geological Survey Organisation. 


\section{REFERENCES}

Alley, R.B., Blankenship, S.T., Rooney, S.T. \& Bentley, C.R., 1989: Sedimentation beneath ice shelves - the view from Ice Stream B. Mar. Geol. 85: 101-120.

Alcison, I., 1979: The mass budget of the Lambert Glacier drainage basin, Antarctica. J. Glaciol. 22: 223-237.

Alonso, B., Anderson, J.B., Diaz, J. I. \& Bartek, L.R., 1992 : Pliocene-Pleistocene seismic stratigraphy of the Ross Sea: evidence for multiple ice sheet grounding episodes. Am. Geophys. Un. Antarct. Res. Ser. 57: 93-104.

Anderson, J.B., 1991: The Antarctic continental shelf: results from recent marine geologic and geophysical investigations. In Tingey, R. (Ed.): THE GEOLOGYOF ANTARCTICA. Oxford University Press, London: 285326.

Aniderson, J.B., Kurtz, D.D., Domack, E.W. \& Balshaw, K.M., 1980: Glacial and glacial marine sediments on the Antarctic continental shelf. J. Geol. 88: 399-414.

Anderson, J.B., Kennidy, D.S., Smith, M.J. \& Domack, E.W., 1991: Sedimentary facies associated with Antarctica's floating icc masses. In Anderson, J.B. \& Ashley, G.M. (Eds): Glacial marine sedimentation; paleoclimatic significance. Geol. Soc. Am. Spec. Publ. 261: 1-26.

BARNES, P.W., 1987: Morphological studies of the Wilkes Land continental shelf, Antarctica-Glacial and iceberg effects. In Eittreim, S.L. \& Hampton, M.A. (Eds): The Antarctic continental margin: geology and geophysics of offshore Wilkes Land. Circum-Pacific Council for Energy and Min. Resour. Earth Sci. Ser. 5A: 175-194.

BARRON, J., LARSEN, B. ET AL., 1991: PROCEEDINGS OF THE OCEAN DRILLING PROGRAM SCIENTIFIC RESULTS 119: 1003 pp.

BAULOAlF, J.G. \& BARRON, J.A., 1991: Diatom biostratigraphy: Kerguelen Plateau and Prydz Bay regions of the Southern Ocean. In Barron, J., Larsen, B. et al. (Eds): Proc. Ocean Drill. Program Sci. Res. 119: 547-598.

Bouron, G.S., 1990: Sedimentary and sea level changes during glacial cycles and their control on glaciomarine facies archirecture. In Dowdeswell, J.A. \& Scourse, J.D. (Eds): Glaciomarine environments: processes and sediments. Geol. Soc. Spec. Publ. 53: 15-52.

Budd, W.F., Keage, P.L. \& Blundy, N.A., 1979: Empirical studies of ice sliding. J. Glaciol. 23: 157-170.

Cooper, A.K., BarretT, P.J., Hinz, K., 'Traube, V., Iettchenkov, G. \& STAGG, H.M.J., 1991a: Cenozoic prograding sequences of the Antarctic continental margin: a record of glacio-eustatic and tectonic events. Mar. Geol. 102: $175-213$.

Coopfr, A., Stagg, H. \& Geist, E., 1991b: Seismic stratigraphy and structure of Prydz Bay, Antarctica: implications from Leg 119 drilling. In Barron, J., Larsen, B. et al. (Eds): Proc. Ocean Drill. Program Sci. Res. 119: 5-26.

DnRDIs, G.F. \& MCCABE, A.M., 1994: Subglacial processes, sediments and landforms - an introduction. Sediment. Geol. 91: 1-8.

Domack, G., Jull, A.J.T. \& Donahue, D.J., 1991: Holocene chronology for the unconsolidated sediments at hole 740A: Prydz Bay, East Antarctica. In Barron, J., Larsen, B. et al. (Eds): Proc. Ocean Drill. Program Sci. Res. 119: $747-750$.

Eyles, N., DAy, T.E. \& Gavican, A., 1987: Depositional controls on magnetic characteristics of lodgement tills and other glacial diamict facies. Can. J. Earth Sci. 24: 2436-2458.
Hallet, B., 1981: Glacial abrasion and sliding: their dependence on the debris concentration in basal ice. Ann. Glaciol. 2: 23-28.

HAMBREY, M.J., 1995: GLACIAL ENVIRONMENTS. UCL Press, London, 296 pp.

Hambrey, M.J., Ehrmann, W.U. \& Larsen, B., 1991: Cenozoic glacial record of the Prydz Bay continental shelf, East Antarctica. In Barron, J., Larson, B. et al. (Eds): Proceedings of the Ocean Drilling Program Scientific Results 119: 77132.

Hart, J.K., 1995: Subglacial erosion, deposition and deformation associated with deformable beds. Progress in Phys. Geogr. 19: 173-191

Hart, J.K., Hindmarsh, R.C.A. \& Boulton, G.S., 1990: Styles of subglacial glaciotectonic deformation within the context of the Anglian ice-sheet. Earth Surface Processes and Landforms 15: 227-241.

King, L.H., Rokoengen, K., Fader, G.B.J. \& Gunleiksrud, T., 1991: Till-tongue stratigraphy. Geol. Soc. Am. Bull. 103: $637-659$.

Kuvvas, B. \& Leitchenkov, G., 1992: Glaciomarine turbidite and current controlled deposits in Prydz Bay, Antarctica. Mar. Geol. 108: 365-381.

LARTER, R.D. \& BARker, P.F., 1989: Seismic stratigraphy of the Antarctic Peninsula Pacific Margin. Geology 17: 731734

Menzles, J., 1989: Subglacial hydraulic conditions and their possible impact upon subglacial bed formation. Sediment. Geol. 62: 125-150.

Mizukoshi, T., Sunouchi, H., Saki, T. \& Tanahshi, M., 1986: Preliminary report of the geological and geophysical surveys of Amery Ice Shelf, East Antarctica. Mem. Nat. Inst. Polar Res., Japan, Spec. Issue 43: 48-62.

O'Brien, P.E., 1994: Morphology and Late Glacial history of Prydz bay, Antarctica, based on echo sounder data. In Cooper, A.K., Barket, P.F., Webb, P-N. \& Brancolini, G. (Eds): The Antarctic continental margin: geophysical and geological stratigraphic records of Cenozoic glaciation, paleoenvironments and sea-level change. Terra Antarctica 1(2): 403-405.

O’Brien, P.E., Franklin, D. \& O'loughlin, M., 1993: Post cruise report - Prydz Bay and Mac. Robertson Shelf, Antarctica, January-March, 1993. Aust. Geol. Surv. Org. Rec. 1993/78: 39 pp.

O'Brien, P.E., Harris, P.T., Quilty, P.G., TAylor, F. \& Wells, P., 1995: Post-cruise report, Antarctic CRC marine geoscience, Prydz Bay, Mac. Robertson Shelf and Kerguelen Plateau. Aust. Geol. Surv. Rec. 1995/29: 123 pp.

STAGG, H.M.J., 1985: The structure and origin of Prydz Bay and Mac. Robertson Shelf, East Antarctica. Tectonophysics 1 14: $315-340$

TEN Brink, U.S. 8 8 SCHNEIDER, C., I 995: Glacial morphology and depositional sequences of the Antarctic continental shelf. Geology 23: 580-584.

VANNEY, J.R. \& JOHNSON, G.L., 1985: GEBCO Bathymetric Sheet 5.18 (Circum-Antarctic) In Jacobs, S.S. (Ed.): OCEANOLOGY OF THE ANTARCTIC CONTINENTAL SHELF. Am. Geophys. Un. Antarct. Res. Ser. 43: $1-4$.

Vorren, T., Lebesbye, E., Andreassen, K. \& Larsen, K.B., 1989: Glacigenic sediments on a passive margin as exemplified by the Barents Sea. Mar. Geol. 85: 251-272.

(accepted 13 August 1996) 